\title{
Episodic Memory in EFL Classroom at Bosowa University
}

\author{
Mardiana \\ mardiana_hd@yahoo.com
}

Baso Jabu

basojabu@unm.ac.id

Sukardi Weda

sukardi.weda@unm.ac.id

State University of Makassar, South Sulawesi, Indonesia

\begin{abstract}
The objectives of this research are (1) to find out whether the use of episodic memory is effective to improve the writing ability of the fifth-semester students of English education department of Bosowa University Makassar and (2) to find out the component of writing that improves the students' writing the highest. The method applied in this research was true experiment design. It involved two groups design. That was experimental and control group. The subjects of this research were taken from two classes at fifth semester A and B in 2014/2015 academic year. The sample consisted of 40 students. They were randomly formed. The data of this research was collected through writing test. The result of the research through students' writing test shows that the students' writing ability improved after treatment. It was supported by the rate of the mean score of writing which were observed in the students' posttest for the five components. The mean score of the experimental group was 71.89 which was higher than of the control group which was only 67.32 and the mean difference was 4.57. The content in the experimental group posttest were 83.50 while in the pretest only 67.50. The improvement of students' score in experimental for the content component was 16 point. It was the highest of all components of writing. It can be concluded that (1) The use of episodic memory is effective to improve the writing ability of the fifth-semester students of English Education Department of Bosowa University Makassar; (2) The component of writing that improves the students' writing the highest is content.
\end{abstract}

Keywords: Episodic memory, writing ability.

\section{INTRODUCTION}

Language is the main means of communication. It consists of four skills, namely: listening, speaking, reading and writing. 
The productive skills are speaking and writing and the receptive skills are listening and reading.

One of the language skills which is problematic in language learning is writing. Picas (1987) states that writing is an instrument of both communication and writing a self expression. The importance of writing seems to be increasing in which people can put their ideas, feeling, opinions, and knowledge into written form more freely (Delasari, 2008:1).

Related to the statement above and what the researcher observed in the field. The researcher found that students' writing ability in the Faculty of Teachership and Educational Science of Bosowa University of Makassar is still low from their mid and final test because their lack of ideas, which will cause many students wasting valuable time just for getting to start and they still lack appropriate elaborations that focused on the central ideas.

It is true that writing, however complex, plays an important role in all language learning. Unfortunately, many students do not realize the essence of writing. They consider writing as a difficult skill. According to Mualdin (1994) at least, there are two factors which cause difficulties in writing. Namely the lack of knowledge to express ideas in the forms of writing and the lack of interest background knowledge of what the writers are going to present to their readers.

Hilalgo (1995) argued that beginning writing pulls us into the world of hard thinking, then set our mind into three questions as follows: what would we write, why we are writing, and how should we write?

Adel Stein and Pival (1976) state that beginning an effective writing is through personal writing which provides the opportunity to write down something elaborating the experience the students have. This supports the ideas about starting writing for students with writing their private world or real life. In the same way, Tarigan (1985) adds that personal writing provides the opportunity to write something in which the students have enough background knowledge of what is being written and personal.

Irawati (2006) found that since the students' ability in writing is poor, they should begin to develop the habit of writing. They could start to write anything they experienced, activities they did, or what they felt. And Mirdawati (1995) states that one simplest way of making writing more meaningful is to have the students write something elaborating the experience they have. 
Mardiana, Jabu, Weda : Episodic Memory in EFL ... $\mid 65$

Episodic memory refers to our ability to recall personal experiences from our past. This aspect of memory organizes information around episodes in our lives. When we try to recall the information, we attempt to reconstruct these episodes by picturing the events in our minds. Episodic memory enables us to recall not only events but also information related to those events (Tulving ,1972).

According to Philip, at. al (2008: 119) episodic memory is the ability to remember specific events from the past, and to use this information to guide present and future behavior, enhances one's level of functioning and obviously confers an adaptive advantage. And also, Gaffan in Easton (1994: 189) said that episodic memory could be considered to be a "snapshot" of the event being remembered. The other researcher Ciaramelli (2008: 519) also conclude that episodic memory retrieval captures attention automatically, and influences the deployment of spatial attention.

According to Belleville and Friends (2006:497) that person with mild cognitive impairment (MCI) can improve their performance on episodic memory when provided with cognitive training. The intervention focused on teaching episodic memory strategies (list recall, face-name association, text memory).

Based on the explanation above, the researcher is interested in carrying out a research entitled " The effectiveness of Episodic Memory to Improve the Writing Ability of the Fifth Semester Students of English Education Department of Bosowa University Makassar".

\section{REVIEW OF LITERATURE}

In the extended ESL Composition Profile Jacob et al. 1981 (in Weigle, 2009 :115) points out five components in writing. They are content, organization, vocabulary, language use, and mechanics.

Wishon and Burks (1980 : 378-387) divide forms of writing into four divisions namely narration, description, exposition, and argumentation.

Tulving (1972) referred to episodic memory as the conscious remembrance of context dependent events that are personally experienced. By contextdependent, it is meant that the cognitive state (temporal, spatial, or affective) provides a context for the information to be remembered. It receives and stores information about temporally dated episodes or events, and temporalspatial relations between them. 
Haselmo (2012:5) consistent with Tulving's definition of episodic memory as involving mental time travel, I have the capability to remember segments of the overall episodic memory in sequential order as if reliving the experience.

The concept of episodic memory according to Endel Tulving (1972) that episodic memory has to do with one's autonoetic awareness of one's experiences in the continuity of subjectively apprehended time that extends both backwards into the past in the form of remembering and forward into the future, in the form of thinking about or imagining or planning for the future. Episodic memory is autobiographical, in that the remembered event has been personally experienced.

Our memory of personal experiences called episodic memory is a mental movie of things we have seen or heard (Slavin, 1997:7). When you remember what you had for breakfast this morning or what happened at your 12th birthday party, you are recalling information stored in your longterm episodic memory. Episodic memory is the memory subsystem that stores information about the episodes or events in our lives. It refers to our ability to recall personal experiences from our past.

Tulving (1972) has seminally defined three key properties of episodic memory recollection. These are a subjective sense of time (or mental time travel), connection to the self, and autonoetic consciousness. Auto noetic consciousness refers to a special kind of consciousness that accompanies the act of remembering which enables an individual to be aware of the self in a subjective time. Aside from Tulving, others named the important aspects of recollection which include visual imagery, narrative structure, retrieval of semantic information and the feelings of familiarity.

By the definition of episodic memory, the model must address the encoding and retrieval of the place and time of the episode. In addition, the model must address the encoding and retrieval of a viewpoint and the direction of action during specific events in the episodic memory. In the model presented here, the components of time, space, and action are bound together in the manner of physics.

According to Aggleton and Brown (1999), the characteristics of episodic memory are: (1) Episodic memory is the memory for what occurred together with the spatial and temporal context in which it occurred. 
Mardiana, Jabu, Weda : Episodic Memory in EFL ... 67

(2) Episodic memory involves memory for a specific experience and therefore involves rapid (one-trial) learning, and a representation of the event that is distinct from that for other events. (3) Episodic memory involves mental time travel and must, therefore require recollection of a specific previous event rather than a simply familiarity judgment of prior occurrence.

According to Jensen (1998:106) said that "Our episodic memory process has unlimited capacity, forms quickly, is easily updated, requires no practice, is effortless, and is used naturally by everyone" (advantages of episodic memory). Episodic processing does have a major drawback: contamination. That occurs when you have too many events or material embedded in the same location". It is like virus renaming all the files in your computer with the same filename-the information is there, but it is nearly useless. This often happens to students who really do know their material but lack the specific "hooks" or mental "file names" to retrieve all their learning (disadvantages of episodic memory).

Strategy in using episodic memory according to Jensen (1998) are (1) Embed emotions in the learning. Add a small daily celebration to heighten emotions. Because the first and last few minutes of a class will make the strongest impressions, invest more time on affecting emotions in the middle of class. (2) We remember material best when it is structured and meaningful. Teachers might want to put the most important material first and last, so it is recalled better. Open and close the class with the three most important words or concepts for the day. Use music, props, or costumes to introduce them. Or, use openings for personal or controversial discussions that engage students emotionally. At the close, ask students to share what they have learned with their classmates. (3) Attitude is important. Tell students, "Yes, you can." Start with a new attitude about memory and recall. Avoid saying, "Oops, I have to go back. I forgot something." A more accurate statement is, "Hey, I just remembered something; I've got to go back." In other words, you never forget anything; you just remembered it later than you wanted to! (4) Learners remember much more when the learning is connected to a field trip, music, a disaster, a guest speaker, or a novel learning location. Follow up with a discussion, journal writing, a project, or peer teaching. Use location (context) changes. To enhance recall and better codify or "mark" the learning, learn concepts in different places so each location is a key clue to the content. Take the class outside for an introduction to something new. 
Procedures in teaching by using episodic memory strategy are : (1) The researcher explained about episodic memory. To make the students easy to understand the researcher explain it based on the researcher experiences. Example we remember something by we connected to another thing that close to us such as place, a thing, and when it happened. (2) The researcher was embed emotions in the learning. Add a small daily celebration to heighten emotions such as in the first treatment turn on romantic music, the second treatment walk around campus area, third treatment turn on instrumental music, fourth treatment turns on motivation movie before the students write about the topic given by the researcher. The topic was their personal experience, an activity they did, or what they felt. (3) The researcher explained about the important of attitude in memory and recall. It can help the students to enhance their motivation to did writing activity by using episodic memory strategy. (4) The students wrote a narrative essay based on the topic that gave from the researcher. The researcher gave different topic every meeting and the topics that the researcher gave can enhance students emotion (my first love, my first day on campus, embarrassing moment, my strongest).

\section{METHOD}

This research employed true experiment design. It involved two groups design. They are experimental and control group. This research conducted at the Bosowa University of Makassar. There are two classes of fifth semester 2015/2016 academic year, consist 30 students in A class and 40 students in $\mathrm{B}$ class, and the total number of population is 70 students. The subject that is included in this sample is 40 students. There are 20 students in A class and 20 students in B class. The technique of sampling is cluster random sampling.

In collecting the data, the researchers apply one kind of instrument, it is writing test. The test is applied in two sections, the first test (the pretest) is intended to find out the prior knowledge of the students' ability in writing and it is given before doing treatment. The second test (the posttest) is given after the treatment. The test used as pretest and posttest is a subjective test, narrative essay. The function of the writing test is to know the students' ability in content, organization, vocabulary, language use, mechanics. The other function is to look for which component of writing ability is improving the highest. 
Mardiana, Jabu, Weda : Episodic Memory in EFL ... 69

Procedure of data collecting used in this research covered two matters: (a) Data collecting through library research, by reading and analyzing book or literature, magazine, thesis, and existing other erudite masterpieces. (2) Data collecting through field research were the existing instrument like tests. A pre-test was given before doing the treatment for both classes. The test in the pre-test was same in the post-test. The pretest runs for 90 minutes. Posttest is given after doing the treatment in both classes. The test in the posttest was same in the pre-test. The posttest runs for 90 minutes. The researcher gives the treatment to the students, both experimental and control group. The treatment is conducted for six meetings and each meeting run for 90 minutes. The experimental group received the treatment by using episodic memory approach and control group receive treatment without using episodic memory approach.

The data was collected by administering the test to the students. The data was analyzed through quantitative analysis. To get the score the researcher used a scoring scale which includes the content, organization, vocabulary, language use and mechanics by using Jacobs' rubric score. After converting the score and classifying the score based on the Bosowa University of MakassarAnd than, calculating the mean score, standard deviation, and $t$ value is done to compare the writings of experimental and control groups by using SPSS 16.00 program (Gay, 2006).

\section{FINDINGS AND DISCUSSIONS}

\section{Students' writing achievement}

This segment deals with the presentation of the result of the students' achievement to write a narrative essay in pre-test and post-test of experimental group and control class.

Before conducting the treatment the researcher gave a pretest to know the prior knowledge of the students in writing. After giving the treatment, the students got the posttest. The pretest and posttest were compared to know the students' writing ability, the frequency and percentage of the students score were firstly tabulated. Then, the researcher determined the quality of the students' score of writing ability for the experiment and control group. 
Students' score of pre-test were classified into seven classifications namely excellent, very good, good, fairly good, fair, poor, and very poor. The frequency and the rate percentage of the students' score of pre-test in experimental and control classes are presented in the following:

Table 2. The Rate Percentage and Frequency of Students' Score of PreTest in Experimental and Control Class

\begin{tabular}{llllll}
\hline Classification & Score & \multicolumn{2}{l}{ Experimental class } & \multicolumn{2}{l}{ Control class } \\
& & Frequency & Percentage & Frequency & Percentage \\
\hline Excellent & $>84$ & 0 & 0 & 0 & 0 \\
Very good & $78-84$ & 1 & 5 & 0 & 0 \\
Good & $71-77$ & 2 & 10 & 3 & 15 \\
Fairly Good & $64-70$ & 7 & 35 & 10 & 50 \\
Average & $57-63$ & 7 & 35 & 5 & 25 \\
Poor & $50-56$ & 3 & 15 & 1 & 5 \\
Very poor & $<50$ & 0 & 0 & 1 & 5 \\
& & & & & \\
\hline Total & 20 & 100 & 20 & 100 \\
\hline
\end{tabular}

Based on the data shown in table 2 the result of the pre-test both of group was none $(0 \%)$ of students got excellent. The result of the students' score in experimental class was three $(5 \%)$ of students got very good, two $(10 \%)$ students got good, seven (35\%) students got fairly good, seven $(35 \%)$ students got average, three $(15 \%)$ students got poor, and there was no student who got very poor. In control class, the students' score was none $(0 \%)$ students got very good, three $(15 \%)$ students got good, ten $(50 \%)$ students got fairly good, five (25\%) students got average, one (5\%) student got poor, and one $(5 \%)$ of student who got very poor.

Table 3 The Mean Score between Pre-Test of Experimental and Control Group in Five Components of Writing

\begin{tabular}{lccc}
\hline \multicolumn{1}{c}{$\begin{array}{c}\text { Components of } \\
\text { Writing }\end{array}$} & Mean score & Difference \\
\hline Content & 67.50 & Control & \\
Organization & 64.50 & 68.00 & -0.5 \\
Vocabulary & 66.50 & 64.50 & 0 \\
Language use & 61.00 & 68.50 & -2 \\
Mechanic & 60.00 & 66.20 & -5.2 \\
\hline Total & 319.50 & 60.00 & 0 \\
\hline
\end{tabular}


Mardiana, Jabu, Weda : Episodic Memory in EFL ... $\mid 71$

Based on Table 3 above, the mean score of all components namely organization and mechanics in experimental and control group pre-test were same. The mean scores of content, vocabulary and language use in the control group were higher than that in the experimental group. The mean score of overall the five components of writing shown the negative difference on -7.7 point which meant that the control group was higher than experimental group although it was not really significant. It means that before giving them treatment, they have same skill of writing.

Table 4 The Rate Percentage and Frequency of Students' Score of Post-Test in Experimental and Control Class

\begin{tabular}{cccccc}
\hline \multirow{2}{*}{ Classification } & Score & \multicolumn{2}{c}{ Experimental class } & \multicolumn{2}{c}{ Control class } \\
& & Frequency & Percentage & Frequency & Percentage \\
\hline Excellent & $>84$ & 1 & 5 & 0 & 0 \\
Very good & $78-84$ & 3 & 15 & 0 & 0 \\
Good & $71-77$ & 6 & 30 & 5 & 25 \\
Fairly Good & $64-70$ & 7 & 35 & 9 & 45 \\
Average & $57-63$ & 3 & 15 & 5 & 25 \\
Poor & $50-56$ & 0 & 0 & 1 & 5 \\
Very poor & $<50$ & 0 & 0 & 0 & 0 \\
\hline Total & & 20 & 100 & 20 & 100 \\
\hline
\end{tabular}

Based on the data shown in Table 4 the result of post-test of the experimental class was increased. One (5\%) student got excellent, three (15\%) students got very good, six (30\%) students got good, seven (35\%) students got fairly good, three (15\%) students got average and there were none students who got poor and very poor.

The result of post-test of control class was also shown in Table 4.3, none students got excellent and very good, five (25\%) students got good, nine (45\%) students got fairly good, five (25\%) students got average, one (5\%) student got poor, and none student got very poor.

The following table shows the specific result of the students' posttest in each component of writing in experimental and control group. The table shows the difference of mean score in five components of writing. 
72 | ELT Worldwide Vol. 3 No. 1 April 2016

Table 5. The Mean Score between Post-Test of Experimental and Control Group in Five Components of Writing

\begin{tabular}{lccc}
\hline \multirow{2}{*}{$\begin{array}{c}\text { Components of } \\
\text { Writing }\end{array}$} & Experimental & Control & Difference \\
\hline Content & 83.50 & 69.50 & 14 \\
Organization & 70.00 & 67.75 & 2.25 \\
Vocabulary & 75.00 & 71.00 & 4 \\
Language use & 69.00 & 68.40 & 0.6 \\
Mechanic & 62.00 & 60.00 & 2 \\
\hline \multicolumn{1}{c}{ Total } & 359.50 & 336.65 & 22.85 \\
\hline
\end{tabular}

The data in Table 5 reveals that the mean score of five components of writing in experimental and control group was different in range 22.85 points. The mean score of experimental was 359.50 while the mean score of the control group was 336.65. It means that the mean score of post-test in the experimental group was higher than the control group. It can be concluded that all of the components of writing in experimental were higher than the control group, therefore, episodic memory was considered more effective to improve the students writing ability.

The following tables were the result of the students' scores of pre-test and post-test in control and experimental group. The tables showed the difference score on the mean score and standard deviation of both of groups.

Table 6. The Mean Score and Standard Deviation of the Students' Pre-Test

\begin{tabular}{lccc}
\hline \multicolumn{1}{c}{ Group } & Sample & Mean Score & $\begin{array}{c}\text { Standard } \\
\text { Deviation }\end{array}$ \\
Control & & & 6.57 \\
Experimental & 20 & 64.92 & 6.97 \\
\hline
\end{tabular}

Based on table 6 the mean score of pre-test in the experimental group was 63.89 which was categorized as average and control group was 64.92 which was categorized as fairly good based on the scoring system by Bosowa University. In line with this, the researcher can conclude that both experimental and control group were nearly at the same level in writing achievement 
Mardiana, Jabu, Weda : Episodic Memory in EFL ... $\mid 73$

Furthermore, the explanation for students' achievement on the post-test score after the treatment was done. In this case, the post-test score was analyzed at the significant level 0.05 or a equals to 0.05 by using inferential statistic through SPSS program version 16.00 The result of post-test as follows:

Table 7. The Mean Score and Standard Deviation of the Students' Post-Test

\begin{tabular}{lccc}
\hline \multicolumn{1}{c}{ Group } & Sample & Mean Score & $\begin{array}{c}\text { Standard } \\
\text { Deviation }\end{array}$ \\
\hline Experimental & 20 & 71.89 & 6.94 \\
Control & 20 & 67.32 & 5.81 \\
\hline
\end{tabular}

Table 7 shows that the mean scores of both experimental and control group were different after treatments. The mean score of the experimental group was $71.89 \quad(63.89<71.89)$ whereas the control group was $67.32(64.92$ $<67.32)$. The mean score of post-test for the experimental group was higher than the control group $(71.89>67.32)$ and the standard deviation for the experimental group was 6.94 and control group was 5.81. The mean score of the groups shows that experimental group was in good category and control group was in the fair good category based on the scoring system used in the Bosowa University.

The t-test was used to measure whether or not there is a significant difference between the results of the students' mean scores in the pretest and the posttest. By using inferential analysis of t-test or test of significance run by SPSS Version 16.00, the significant differences can be easier to analyze. The level of significance is $(\alpha)=0.05$ and the degree of freedom $(\mathrm{df})=38$, $\mathrm{N} 1+\mathrm{N} 2-2$, the number of students (each 40 ) minus 2. The following table illustrates the t-test value result:

Table 8. The Probability Value of T-test of Pre-test in Experimental and Control Group

\begin{tabular}{cccc}
\hline Variables & $\begin{array}{c}\text { Probability } \\
\text { Value }\end{array}$ & $\boldsymbol{\alpha}$ & Remarks \\
\hline $\begin{array}{c}\text { Pre-test of control } \\
\text { and experiments } \\
\begin{array}{c}\text { Class } \\
\text { Post-test of } \\
\text { control and }\end{array}\end{array}$ & 0.634 & 0.05 & $\begin{array}{c}\text { Not Significantly } \\
\text { different }\end{array}$ \\
experiments Class & 0.030 & 0.05 & Significantly different \\
\hline
\end{tabular}


Referring to the result of the students' writing obtained the stated in finding above, the researcher used t-test in inferential statistic through SPSS version 16.00 program to test the hypothesis. Based on the statistic result shown in table 8 , it was concluded that pretest and post-test of experimental and control group, the researcher found that the p-value (probability value) was lower than $\alpha(0.030<0.05)$ and the degree of freedom was 38 . The t-test value of post-test was remarked significantly different. It showed that Episodic memory effective to Improve the writing ability of the fifth-semester students of English Education Department of Bosowa University Makassar.

The data which were collected through students' writing test shows that the students' writing ability improved considerably either in the control group on in the experimental group. In experimental group the students gave the treatment by using episodic memory strategy in teaching writing, they recall their personal experience from their past. This strategy success to improve the students writing ability. It is same with previous related studies from Irawati (2006) said that since the students ability in writing is poor. They should begin to develop the habit of writing anything they experienced, the activity they did, and what they felt. And also from Belleville and friends (2006) found that person with MCI can improve their performance on episodic memory when provided with cognitive training. The intervention focused on teaching episodic memory strategies. It was supported by the rate of the mean score of writing which were observed in the students' posttest for the five components. The mean score of pre-test in the experimental group was 63.89 which classified into 'average' category while the posttest was 71.89 and which was classified into 'good' category. The data in the previous section showed that episodic memory gave better effect in learning writing than the conventional one. It could also be seen from the mean score in which the mean score of post test of experimental group and control group were different after being given treatment. The mean score of the experimental group was 71.89 which was higher than of the control group which was only 67.32 and the mean difference was 4.57 .

The component of writing that show the students' highest writing achievement was content. Based on table 5 that in the post-test, content in the experimental group were 83.50 while in the pretest only 69.60. The improvement of students' score in experimental for the content component was 16 point, for the organization was 5.5 point, vocabulary was 8.5 point, language use was 8 point, and the mechanic was 2 point. Based on the theory of episodic memory as the conscious remembrance of context dependent events that are personally experienced. 
It is meant that the cognitive state (temporal, spatial, or affective state) provides a context for the information to be remembered. It can be possible that the ability of writing that can improve the highest was content. students can remember where they were and what they were doing (even the color of clothes they were wearing at the time) because the students were trained to think the ideas which related with the topic that incorporates all the relative experiences, the knowledge and the total background where students are immersed.

\section{CONCLUSION AND SUGGESTIONS}

Based on the findings and discussion in the previous, the researcher concluded that The use of episodic memory is effective to improve the writing ability of the fifth-semester students of English Education Department of Bosowa University Makassar. It was proved by the mean score of the students' posttest in the experimental group was 71.89 which was higher than of the control group which was only 67.32. It means that there was a higher improvement in experimental class.

The component of writing that show the students' highest writing achievement is content. The content in the experimental group posttest were 83.50 while in the pretest only 67.50. The improvement of students' score in experimental for the content component was 16 point. It was the highest of all components of writing.

Related with the conclusion, the researcher would like to propose some suggestion: (1) It is strongly suggested that the teaching of writing through the implementation of episodic memory should be continually implemented in English Education Department of Bosowa University Makassar. (2) In getting a good writing, teachers are suggested to give more attention to the students on five components of writing continually, so that the students can compose and organize their writing perfectly. 
76 | ELT Worldwide Vol. 3 No. 1 April 2016

\section{REFERENCE}

Adel Stein, English \& Jean G. Pival. 1976. The Writing Commitment. New York: Harcourt Brace java Novich Inc.

Aggleton, J.P. and Brown, M.W. 1999. Episodic Memory, Amnesia, and The Hippocampal-Anterior Thalamic Axis. Behav. Brain Sci., 22: 425-489.

Belleville., at. al. 2006. Improvement of Episodic Memory in Person with Mild Cognitive Impairment and Healthy Older Adult: evidence from a Cognitive Intervention Program. Canada: Karger online publisher.

Ciaramelli, Elisa. at. al. 2008. Episodic Memory for Spatial Context Biases Spatial Attention. Canada: University of Toronto.

Delasari. 2008. “The analysis of Students' Ability and Interest to write Diary". Unpublished Thesis. Graduate Program of the State University of Makassar.

Easton, Alexander. 2008. A New Working Definition of Episodic Memory: Replacing "When, With, Which". Handbook of Episodic Memory. UK: Elsevier.

Gay, Lorraine R.et al.2006. Educational Research: Competences Analysis and Application. Columbus: Merill Publishing Company.

Hasselmo, Michael E. 2012. How We Remember. Brain Mechanisms of Episodic Memory. England: The MIT Press.

Hilalgo, Araceli. C et al. 1995. Getting Started: Materials Writers on Materials Writing. Singapore: SEAMEO Regional language center.

Irawati. 2006. "The Students' Ability and Interest in Writing Journal”. Unpublished Thesis. Makassar: UNISMUH Makassar.

Jensen, Eric. 1998. Teaching With The Brain in Mind. USA: Association for Supervision and Curriculum Development (ASCD).

Kaylor, M. (2008). Use Digital Storytelling to Improve Your Students' Writing Skills. CEC Today. Council for Exceptional Children. 
Mardiana, Jabu, Weda : Episodic Memory in EFL ... 177

Mindarwati, Andi. 1995. "The Ability to Write Narration Using Personal Experience". Unpublished Thesis. Ujung Pandang: IKIP Ujung Pandang.

Mualdin. 1994. "The Ability to Produce Complex Sentences in Writing by Seventh Semester Students of English Department of FPBS IKIP Ujung Pandang" . Unpublished Thesis. Ujung Pandang: IKIP Ujung Pandang.

Philip, at. al. 2008. Handbook of Episodic Memory vol 18. "Emotion and Episodic Memory.” Netherlands: Elsevier.

Picas, Anita. 1987. Teaching English writing: Essential Language teaching Series. London: The Macmiltan Publisher Inc.

Slavin, R. E. 1997. Educational Psychology: Theory and Practice. Boston: Allyn \& Bacon.

Tarigan, Henry Guntur. 1985. Menulis sebagai suatu keterampilan. Bandung: Angkasa.

Tulving, E. 1972. Episodic and Semantic Memory: In E Tulving \& W. Donaldson (Eds), Organization of Memory (pp.381-403). New York: Academic Press.

Weigle, Sara Cushing. 2009. Assessing Writing. New York: Cambridge University Press.

Wishon, G. E and Burks, J. M. 1980. Let ${ }^{e e}$ s Write English. American Book Company. New York: Litton Educational Publishing International. 